\title{
References
}

1) Frederic, J. 1951. Compt. rend. Soc. Biol., 145. 2) Frederic, J. \& Chèveremont-Comhaire, S. 1953. Arch. Biol., 64. 3) Frederic, J. \& Chevremont-Comhair, S. 1954. Compt. rend. Soc. Biol, 148. 4) Bierling, R. 1954. Z. Krebstorsch., 60. 5) Tobioka, T. \& Biesele, J. J. 1956. J. B. B. C., $2 . \quad$ 6) Nagatsu-Ishibashi, I. 1960. Proc. Japan. Histochem. Ass., 1.

\section{Studies on the Mechanism of Antibody Formation by Fluorescein Labelled Protein}

\author{
I. Bovine Albumin \\ Shigeru Arimori and Satoru Higashi \\ Department of Internal Medicine Okayama University Medical School \\ (Director Prof. Kiyoshi Hiraki)
}

There have been many excellent reports concerning immunological studies on foreign protein injected into heterologous animals, and it is now widely recognized that plasma cells are the antibody producing cells. However, much of the fate of the injected antigen and the mechanism of antibody production remain obscure. In an attempt to clarify these points, we have studied the relation between the fate of the antigen and the appearence of antibody producing cells that occurs in the first primary sensitization.

\section{Materials and Methods}

Normal white, male rabbits weighing $2 \mathrm{~kg}$., and as antigen, refined bovine albumin dissolved in physiological saline solution were used. Fifty mg. per kg. of the antigen was injected into the animals through the ear vein, and after certain interval following the injection, the animals were sacrificed by exsanguination. Then, pertinent organs were removed and immediately frozen in dry ice-aceton. Frozen-sections, $4 \mu$ in thickness, were made in the cryostat at $-18^{\circ} \mathrm{C}$.

The localisation of the antigen and antibody in each organ were pursued by the staining method shown in Table 1. As controls, 1) sections of organs from normal healthy rabbits, 2) staining with antigens other than bovine albumin and antibodies different from the anti-bovine albumin serum, 3) Fluorescein labelled normal serum, 4) neutralization test, and 5) blocking method were employed to exclude the non-specific fluorescence as much as possible.

In both direct and indirect methods, the fluorescence was not strong enough 
Table 1. FLUORESCEIN LABELLED PROTEIN METHOD

I. Preparation of sections and imprinting

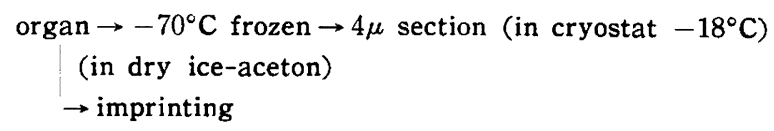

II. Fixation $95 \%$ ethylalcohol $15 \mathrm{~min} .\left(37^{\circ} \mathrm{C}\right)$

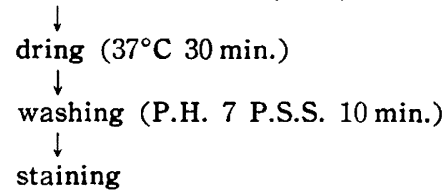

III. Conjugation of fluorescein isothiocyanate with antiserum globulin saline $10 \mathrm{ml}+\mathrm{CO}_{3}-\mathrm{HCO}_{3}$ buffer (P.H. 9) $3.0 \mathrm{ml}$

to permit the histo-morphological identity. Therefore, the complement method which showed a stronger staining was used in conjunction with the two methods. Furthermore, peripheral blood counts of the animals electrophoretic patterns of the serum protein and serum precipitation values by modified Oudin's and Ouchterlony's methods were studied.

In addition, frozen and paraffin sections of each organ were stained with hematoxylin and eosin, Giemsa stain, and methyl green-pyronine, and these were compared with the corresponding fluorescent stains.

\section{Results}

1. Peripheral blood counts and serum electrophoretic patterns.

The alternation of the peripheral blood counts is shown in Fig. 1. In the serum electrophoresis, the albumin fraction increased in both percentage and absolute amount till 24th hour after the antigen injection, and then decreased gradually. And in the 2nd week, it decreased rather markedly. In contrast, $\gamma$-globulin increased gradually between the 1st and 2nd week (Fig. 2).

II. Transition of the serum antigen and antibody (Fig. 3).

The antigen began to diminish rapidly after 2 hours following the injection and disappeared completely in 7 days. The antibody was found from the 4 th day till the $3 \mathrm{rd}$ week, the highest titer of which was seen on the 7 th day. The same results were obtained by the Ouchterlony's method. 


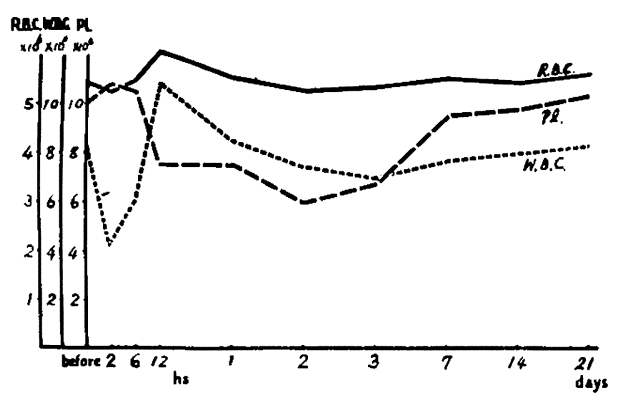

Fig. 1 Peripheral Blood Picture

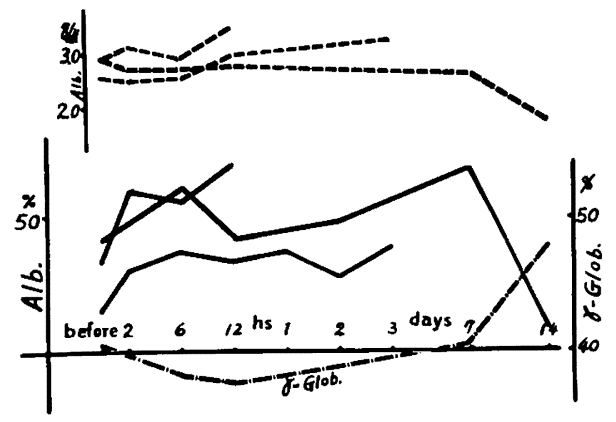

Fig. 2 Electrophoretic Pattern

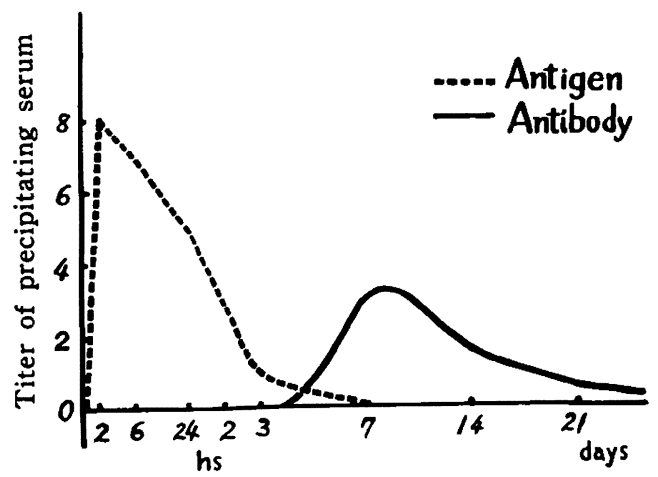

Fig. 3 Transition of serum antigen and antibody - Precipitin test -

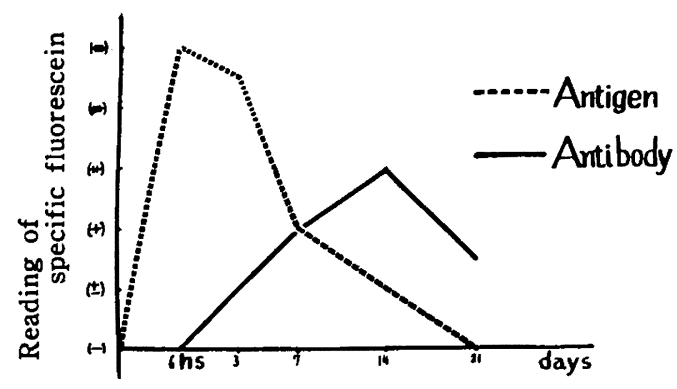

Fig. 4 Alternation of organ antigen and antibody - fluorescein labelled protein method - 


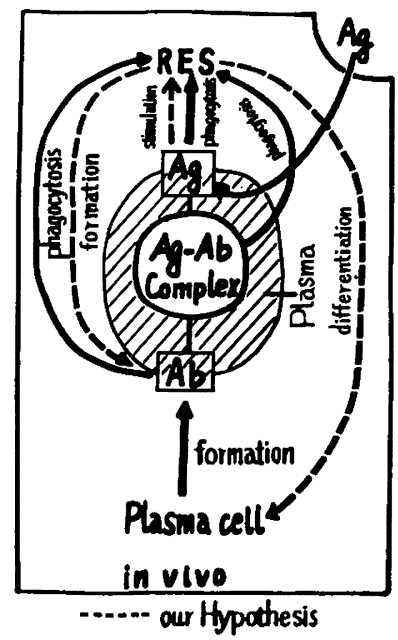

Fig. 5 Schematic Representation of Antigen and Antibody System in Vivo

III. Alternations of organ antigen and antibody as determined by fluorescein labelled protein (Fig. 4).

The injected antigen in the organs was found to be the maximum in 6 hours after the injection, started to diminish in 2 days, was only trace in one week, and hardly detectable in 2 weeks. The distribution of the antigen in various organs in 6 hour after the injection was investigated. As a result, it was found that the liver contained the highest amount followed by the spleen and the lung. And it was also found in the bone marrow, lymph nodes, kidney, connective tissue and reticulo-endothelial cells of each organ, vascular endothelial cells and perivascular connective tissue, reticulum cells and lymphoid round cells of the spleen and lymphnodes, kupffer cells of the liver, and glomeruli and tubular epithelium of the kidney. On the other hand, the antibody in the organs began to appear in 3 days, became the maximum in 1 to 2 weeks, and decreased in 3 weeks. Ist distribution study showed the highest amount in the spleen and next in the bone marrow. Also the mesenteric lymph nodes, lung, kidney, and liver showed the antibody in the declining order. The specific fluorescence was observed in lymphoid round cells, plasma cells and occasionally in reticulo-endothelial cells of the spleen, lymph nodes, and bone marrow; in Kupffer's cells and Glisson's capsule of the liver; and in vascular adventitia of other organs.

\section{Discussion}

We have observed the alternation of antigen and antibody in the primary response against bovine albumin. In summary, the majority of the injected antigen was found in the reticulo-endothelial cells and the connective tissue of the animal, while the antibody was found in the plasma cells as well as in the reticulo-endothelial cells in the early stage, and also in the aggregated plasma cells of the reticulo-endothelial and lymphoid tissue, as the serum 

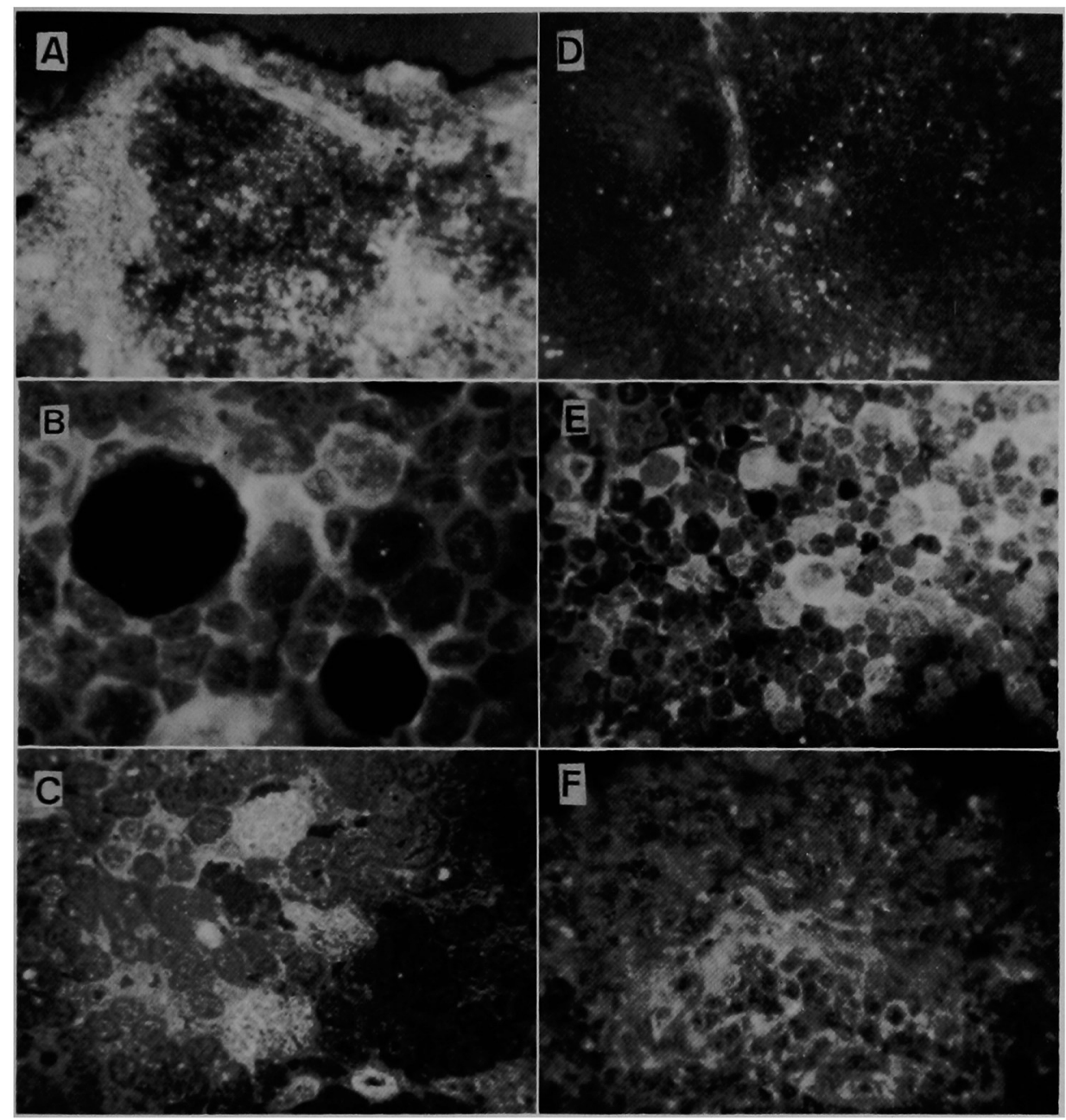

Phot. A ; Spleen, distribution of the antigen ( $6 \mathrm{hs}$, frozen section).

Phot. B ; Spleen, the antigen in reticulo-endothelial cell (6 hs, imprint).

Phot. C ; Kidney, distribution of the antigen ( $6 \mathrm{hs}$, frozen section).

Phot. D ; Spleen, distribution of the antibody (7 days, frozen section).

Phot. E ; Lymph node, distribution of the antibody (7 days, imprint).

Phot. F ; Lung, the antibody in plasma cells (7 days, frozen section).

antibody titer increase. From these observations the antibody producing cells are considered to be the plasma cells. And it is also speculated that the positive fluorescence seen in some of the reticulo-endothelial cells is due to their phagocytosis of the antibody produced by the plasma cells or their phagocytosis of the antigen-antibody complex present in the plasma.

Although definite conclusions cannot be drawn from the present study alone on the antibody producing ability of the reticulo-endothelial cells and the interrelationship of the reticulo-endothelial cells to the plasma cells, it is very likely that the reticulo-endothelial cells phagocytize the antigen which stimulate them and at some time produce the antibody. They change into more differe- 
ntiated plasma cells exclusively devoted to the formation of the antibody. To prove this hypothesis further studies are necessary.

\section{Conclusion}

We have observed the alternation of antigen and antibody in rabbits by means of fluorescein labelled bovine albumin as antigen and investigated the mechanism of antibody production.

\section{References}

1) Coons, A. H. and M. H. Kaplan: J. Exp. Med., 91, 1, $1950 . \quad$ 2) Goldwasser, R. A. and Shepard, C. C. : J. Imm., 80, 122, $1958 . \quad 3)$ Kyogoku, M.: Nippon Taisitugaku Zassi, 24, 351, 1959. 4) Nakashima, Y.: Nippon Taisitugaku Zassi, 25, 515, 1961. 5) Ofuji, T. : Okayama Igakkai Zassi, 74, 1, 1962.

\section{Discussion}

Dr. Tanaka

The primary response of antibody production is generally very weak to be stained by fluorescence method. In your present studies, many cells, especially reticulum cells, showed excessive fluorescence. This is very impotant findings. I think some of them seem to be of autofluorescence or nonspecific fluorescence.

Dr. Arimori.

I don't think there are any specific difference of antibody distribution in the primary and secondary response. I will show you the findings of secondary response in next time. Antibody in reticulum cells might be originated from that of plasma cells or reacted antigen-antibody in serum. In addition, reticulum cells also may produce antibody. We sufficiently recognized the specificity with various control staining such as block method and methods with heterogenous sera, fluorescent sera, heterogenous antigen and heterogenous fluorescent antigens. Fluorescein labelled protein was purified through absorption with DEAE, cephadex columm, MLP, rabbit bone marrow powder and human liver powder.

Dr. Hamashima

The reactive cells of primary response usually disappear after 3 days. The specific antibody of secondary response is different from that of primay response. It is desirable to observe with double staining in identical tissue sections to study the relationship between antigen and antibody. 